\title{
Penerapan Cisco Packet Tracer Sebagai Media Pembelajaran Jaringan Untuk Meningkatkan Hasil Belajar Siswa Pada Kelas X TKJ di SMK 2 Ibrahimy Sukorejo
}

\author{
Arico Ayani Suparto ${ }^{1}$, Rahmat Shofan Razaqi ${ }^{2}{ }^{1}$ STKIP PGRI SITUBONDO \\ ${ }^{2}$ STKIP PGRI SITUBONDO \\ 1aca13rico@gmail.com, ${ }^{2}$ fanslaught@gmail.com
}

\begin{abstract}
Abstrak : Arico Ayani Suparto ${ }^{1}$, Rahmat Shofan Razaqi ${ }^{2}$ Untuk meningkatkan kualitas pembelajaran dapat dilakukan dengan menerapkan strategi atau metode pembelajaran efektif di kelas, memperdayakan siswa serta memanfaatkan sumber yang ada di lingkungan sekolah. Aktifitas siswa dalam kegiatan mengajar tersebut ditandai dengan pertisipasi siswa dalam melaksanakan tugas yang diberikan guru. Aktifitas belajar siswa yang rendah akan berdampak pada ketidaktuntasan siswa. Salah satu faktor yang mempengaruhi pembelajaran yang diterapkan guru kurang membangkitkan gairah siswa. Tujuan dari penelitian ini adalah ingin mengetahui peningkatan aktifitas dan belajar siswa melalui penerapan media pembelajaran Penerapan Cisco Packet Tracer Sebagai Media Pembelajaran Jaringan Untuk Meningkatkan Hasil Belajar Siswa Pada Kelas X TKJ di SMK 2 Ibrahimy Sukorejo. Penelitian ini dilakukan sejak tanggal 28 April - 1 Mei 2018 dengan obyek penelitian yaitu siswa kelas X TKJ sebanyak 24 siswa. Untuk memperoleh data dalam penelitian menggunakan metode observasi,tes.dan dokumentasi. Analisis data pada penelitian ini menggunakan analisa deskriptif kualitatif. Hasil yang di peroleh dalam penelitian menunjukkan peningkatan hasil belajar siswa. Pada pra-siklus ketuntasan klasikal 54\%, setelah tindakan penelitian hasil ulangan harian pada siklus I diperoleh ketuntasan klasikal $66 \%$. Hal ini menunjukkan adanya peningkatan hasil belajar siswa, meskipun pembelajar aplikasi Cisco Packet Tracer pada siklus I belum mencapai ketuntasan klasikal pembelajaran Cisco Packet Tracer dilanjutkan pada siklus II. Hasil analisis ulangan harian pada siklus II diperoleh ketuntasan klasikal 87\%, hal ini menunjukkan bahwa tercapainya ketuntasan belajar secara klasikal. Kesimpulan dalam penelitian ini bahwa model pembelajaran yang digunakan guru sangat mempengaruhi terhadap aktivitas dan hasil belajar siswa, hal ini terbukti bahwa dalam penerapan Cisco Packet Tracer Sebagai Media Pembelajaran Jaringan Untuk Meningkatkan Hasil Belajar Siswa Pada Kelas X TKJ di SMK 2 Ibrahimy Sukorejo menjadi skor ketuntasan sebesar $85 \%$ secara klasikal.
\end{abstract}

Kata kunci: Media Pembelajaran Cisco Packet Tracer, Hasil Belajar 


\begin{abstract}
To improve the quality of learning can be done by applying strategies or methods of effective learning in the classroom, empower students and utilize existing resources in the school environment. Student activity in teaching and learning activities is marked by the participation of students in carrying out the task given by the teacher. Low student learning activities will have an impact on student's non-completeness. One of the factors that influence the lesson that is applied by the teacher is less arousing student's learning. The purpose of this research is to know the increase of activity and student learning outcomes trought application of Learning Media Using Cisco Packet Tracer Application To Improve Student Learning Outcomes of Class X In Basic Network Subject In SMK 2 Ibrahimy Sukorejo Lesson year 2018/2019. This research was conducted from28 April - 1 Mei 2018 with the object of research that is students class X TKJ as many 24 student. To obtain data in research using the method of observation, test and documentation. Data analysis in this research use qualitative descriptive analysis. The results obtained in the study showed improvement in student learning outcomes. In the pre-cycle of of classical completeness 54\%, after the action of research daily repetition in cycle I obtained $66 \%$ classical completeness. This indicates an increase in student learning outcomes, althought the Cisco Packet Tracer application learning in cycle I has not yet achieved the caliber of learning. The Cisco Packet Tracer application is continued in cycle II. The result of daily test analysis on cycle II was $87 \%$ classical completeness, it shows that the result achievement of learning completeness in classical. The conclusion in this rearch that the learning model used by the teacher is very influence to the activity and result of student learning, it is proven that in applying of learning Cisco Packet Tracer application can improve result of activity and result of student learning of $\mathrm{X}$ TKJ class on basic network subjek to scores of $85 \%$ classically.
\end{abstract}

Keywords : learning media cisco packet tracer, learning outcomes

PENDAHULUAN

Latar Belakang Masalah

Jaringan Dasar merupakan

salah satu mata pelajaran yang

terdapat pada kurikulum Kurikulum

2013 yang termasuk pada ranah C2.
C2 merupakan pemahaman yang

mencangkup kemampuan untuk menyerap pengertian dari hal-hal yang telah dipelajari, pada jenjang ini siswa di tuntut untuk mengerti dan memahami konsep yang dipelajari. 
Mata pelajaran ini harus dikuasai siswa SMK terlebih jurusan Teknik Jaringan Komputer (TKJ).

Siswa tidak hanya mengandalkan guru yang memberikan materi dengan metode ceramah untuk dapat menguasai materi mata pelajaran komputer dan jaringan dasar secara utuh, misalnya dalam materi jaringan dasar dibutuhkan latihan perhitungan

IPAddress. Hasil perhitungan komputer yang ada didalam lab.komputer menghasilkan beberapa IP Address yang akan di terapkan sehingga menjadi suatu jaringan yang bisa di bangun. Dibutuhkan

suatu media yang dapat memvisualisasikan penerapan $I P$ Address tersebut pada komputer. Begitu juga dengan beberapa materi yang lain dalam mata pelajaran jaringan dasar. Salah satu langkah untuk menangani permasalahan tersebut dapat menggunakan sebuah aplikasi Cisco Packet Tracer sebagai media pembelajaran untuk memvisualisasikan penerapan jaringan. Melalui aplikasi Cisco Packet Tracer jaringan, bayangan siswa mengenai jaringan akan lebih terbentuk, dan siswa dapat mempraktikkan penerapan jaringan tersebut.

\section{Tujuan utama Cisco Packet} Tracer adalah untuk menyediakan alat bagi siswa dan pengajar agar dapat memahami prinsip jaringan komputer. Simulator Cisco Packet Tracer telah sering digunakan sebagai media pembelajaran dan pelatihan, serta dalam bidang penelitian simulasi jaringan komputer (A Nugroho;2015).

Model pembelajaran yang tepat juga dibutuhkan untuk mencapai tujuan pembelajaran untuk menSetting IP Address, selain media visualisasi jaringan yang telah disebutkan. Penggunaan model pembelajaran yang bervariasi dirasa mampu untuk meningkatkan keaktifan dan semangat peserta didik dalam mengikuti proses belajar mengajar, karena dengan pembelajaran yang tepat akan mempermudah serta memperlancar siswa yang mengikuti dan memahami pelajaran, semakin baik siswa mengikuti dan memahami mata pelajaran,akan semakin baik hasil belajarnya. 
Berdasarkan hasil observasi di dalam kelas untuk pelajaran jaringan dasar, siswa merasa kesulitan dengan materi IP Address, yang merupakan pelajaran hitungan yang mirip dengan matematika. Padahal, materi IP Address merupakan salah satu pelajaran yang harus di kuasai siswa dalam mata pelajaran jaringan dasar. Hal ini merupakan salah satu faktor yang membuat beberapa siswa tidak lulus ketika ketika ulangan materi $I P$ Address, dan mengindikasikan bahwa proses pembelajaran jaringan dasar belum selesai dengan harapan.

Melalui penerapan aplikasi Cisco Packet Tracer, diharapkan siswa kelas X SMK 2 Ibrahimy

Sukorejo dapat mengalami
peningkatan hasil belajar siswa.
Berdasarkan hal tersebut, maka
dipandang perlu untuk mengkaji
suatu penerapan pembelajaran
melalui penelitian berjudul:
"Penerapan Cisco Packet Tracer
Sebagai Media Pembelajaran
Jaringan Untuk Meningkatkan Hasil
Belajar Siswa Pada Kelas X TKJ di
SMK 2 Ibrahimy Sukorejo"

\section{Rumusan Masalah}

Berdasarkan latar belakang maka permasalahan yang ingin dikaji dalam penelitian ini adalah : Apakah Penerapan Cisco Packet Tracer

Sebagai Media Pembelajaran Jaringan Dapat Meningkatkan Hasil Belajar Siswa Pada Kelas X TKJ di SMK 2 Ibrahimy Sukorejo ?

\section{Tujuan Penelitian}

Penelitian ini bertujuan untuk mengetahui ada tidaknya peningkatan hasil belajar dengan menggunakan strategi pembelajaran Penerapan Cisco Packet Tracer pada Siswa Pada Kelas X TKJ di SMK 2 Ibrahimy Sukorejo.

\section{KAJIAN TEORI}

Dasar Pandangan Teori Tentang Strategi Media Aplikasi Cisco Packet Tracer

Dalam kegiatan pembelajaran, seringkali peserta didik dihadapkan pada materi-materi yang bersifat kompleks, abstrak, dan sulit dipahami. Materi seperti itu sering tidak efektif dengan metode ceramah. Untuk itu diperlukan alat bantu berupa media. Media dapat membantu pendidik maupun peserta 
didik dalam proses belajar mengajar.

Melaui media suatu proses pembelajaran dapat menjadi lebih menarik dan menyenangkan.

Kata media sendiri berasal dari bahasa latin yang merupakan bentuk jamak dari kata medium, yaitu secara terpisah berarti perantara atau pengantar, yang mana dapat digunakan dalam rangka hubungan atau komunikasi dalam pengajaran antara guru dan siswa, sehingga dapat pula sebagai alat bantu belajar mengajar di dalam kelas maupun didalam kelas. Sedangkan pembelajaran adalah segala sesuatu yang dapat membawa informasi dan pengetahuan dalam interaksi yang berlangsung antara pendidik dengan peserta didik (asyhar.2012:7).

Media pembelajaran yang digunakan pada penelitian ini adalah perangkat lunak Cisco Packet Tracer. Perangkat lunak Cisco Packet Tracer dalam penelitian ini digunakan sebagai media untuk menunjang kegiatan belajar mengajar didalam kelas. Dengan Cisco Packet Tracer siswa akan lebih mudah dalam melakukan praktik pembuatan simulasi jaringan.

\section{perangkat lunak Cisco Packet}

\section{Tracer}

Perangkat lunak Cisco Packet Tracer adalah alat simulator alat jaringan yang sering di gunakan sebagai media pembelajaran dan pelatihan, dan juga dalam bidang penelitian simulasi jaringan komputer. Perangkat lunak ini dibuat oleh perusahaan Cisco systems, perusahaan yang bergerak dalam bidang jaringan komputer. Menurut Cisco Packet Tracer Data Sheet (dalam Mulyadi,2014:4) tujuan dibuat perangkat lunak Cisco Packet Tracer adalah untuk menyediakan alat bagi siswa dan pengajar agar dapat lebih mudah dalam memahami prinsip jaringan komputer dan juga membangun keterampilan di bidang jaringan komputer.

Cisco Packet Tracer memiliki keunggulan dan kemudahan dibandingkan dengan simulator simulator jaringan lainnya, seperti GNS30,Dynamips, dan Dynagen. Salah satu keunggulannya adalah kita bisa mengatur rancangan sebuah jaringan dengan mudah dan penempatan jaringan juga dapat 
kelas menurut Sudjana (2003:107-200) adalah sebagai

diatur dan ditentukan dengan baik sesuai dengan keinginan kita. Selain itu sangat mudah untuk dipasang dalam komputer. Cisco Packet Tracer juga dapat berjalan pada istem berspesifikasi rendah. Cisco Packet Tracer juga dapat berjalan pada system operasi windows maupun linux.

\section{Hasil Belajar}

Proses adalah kegiatan yang dilakukan oleh siswa mencapai tujuan pengajar, sedangkan hasil belajar adalah kemampuan yang dimiliki siswa setelah ia menerima pengalaman belajarnya. Horward Kingsley (dalam Nana Sudjana, 1989:22) membagi tiga macam hasil belajar, yakni (a) keterampilan dan kebiasaan, (b) pengetahuan dan pengertian, (c) sikap dan cita-cita. Masing-masing jenis hasil belajar dapat diisi dengan bahan yang telah diterapkan dlam kurikulum.

\section{METODE PENELITIAN}

\section{Rancangan Penelitian}

Penelitian ini menggunakan Penelitian Tindakan Kelas (PTK). Adapun ciri-ciri penelitian tindakan berikut:

1. Metode yang di terapkan pada PTK harus menunjang guru dalam tugas mengajar.

2. Siklus-siklus dipilih dan di tempuh untuk membentuk pengetahuan yang ditargetkan.

3. Pengumpulandatatidak memerlukan waktu yang berlebihan.

4. Metode yang digunakan harus realible.

5. Isu yang diteliti adalah yang krusial, yang mengganjal.

6. Guru peduli pada etika disaat PTK dilakukan.

7. Hasil PTK berdampak pada sekolah.

8. Jenis penelitinan ini adalah penelitian tindakan kelas.

Sedangkan menurut Hobri (2007:1) Penelitian tindakan kelas merupakan bagian dari penelitian tindakan secara umum yang memiliki beberapa pengertian yaitu:

1. Penelitian yang dilakukan di kelas. 
2. Penelitian tindakan yang

Menurut Hobri (2007:17)

menyangkut masalah-masalah

Observasi dilakukan untuk

kelas (interaksi siswa dan guru)

3. Peneelitian tindakan kelas yang menyangkut masalah pendidikan dan pembelajaran.

Sedangkan menurut Sunardi

(2000:3) penelitian tindakan merupakan penelitian atau kajian secara sistematis dan terencana yang dilakukan oleh peneliti dan praktis (dalam hal ini guru), untuk memperbaiki pembelajaran dengan jalan mengadakan perbaikan atau perubahan dan mempelajari akibat yang ditimbulkan

\section{Teknik Pengumpulan Data}

Teknik pengumpulan data merupakan cara yang digunakan oleh peneliti guna memperoleh data. Penggunaan metode penelitian yang tepat sangat penting dalam sebuah penelitian ilmiah. Adapun metode pengumpulan data yang digunakan peneliti dalam penelitian ini adalah :

- Metode Observasi

- Metode Tes

- Metode Dokumentasi

\section{Metode Observasi} kegiatan pembelajaran. Kegiatan yang diamati meliputi aktivitas pengajar dan aktivitas siswa dalam pembelajaran. Kegiatan observasi ini dilakukan bersama observer dan peneliti untuk meraih data tentang aktivitas siswa selama proses pembelajaran diantaranya membaca materi, diskusi menjawab pertanyaan. Kegiatan guru (Peneliti) dalam mengajar diamati oleh guru bidang studi, aktivitas tersebut meliputi penyampaian langkahlangkah pembelajaran, menyampaikan materi, mengajukan pertanyaan, membimbing kelompok belajar, dan menutup pelajaran.

Observasi pada aspek afektif meliputi kehadiran, tanggung jawab, keaktifan, dan kejujuran siswa. Sedangkan observasi pada aspek psikomotor meliputi kemampuan siswa dalam mengoperasikan komputer secara umum, membuat topologi jaringan, dan kegiatan setelah melakukan pembelajaran. Hasil observasi kemudian dianalisis 
untuk megetahui kelas mana yang lebih baik.

\section{Metode Tes}

Metode tes merupakan salah satu cara untuk mengumpulkan data yang berupa nilai-nilai yang diperoleh siswa untuk mendukung tercapainya hasil penelitian. Tes yang dapat digunakan dalam penelitian bisa berupa pilihan ganda, soal isian atau uraian dan tes praktikum.

Tes adalah pertanyaanpertanyaan atau latihan yang diberikan untuk mengetahui dan mengukur pengetahuan, keterampilan, intelegensi, bakat dan kemampuan siswa dalam memahami dan menguasai materi. Dalam penelitian ini jenis tes yang digunakan adalah tes tulis yang berbentuk uraian. Kelebihan penggunaan tes dalam bentuk ini dapat memunculkan kreativitas siswa dalam berpikir dan menyusun jawaban sesuai pendapat dan pemikiran mereka sendiri. Sehingga hanya siswa yang telah menguasai materi dengan baik yang mampu memberikan jawaban yang benar.
Sedangkan kelemahannya yaitu jawaban siswa yang beragam sehingga membutuhkan waktu yang cukup lama untuk mengoreksi jawaban siswa dan bagi siswa yang belum paham, maka akan mengisi lembar jawaban.

Sedangkan tes praktek membutuhkan interaksi yang berbentuk praktek dan latihan pada umumnya digunakan untuk proses pembelajaran yang memerlukan latihan keterampilan yang harus dilakukan terus-menerus oleh siswa.

\section{Metode Dokumetasi}

Metode dokumentasi, yaitu mencari data mengenai hal-hal atau variable yang berupa catatan, transkrip, buku, surat kabar, majalah, prasasti, notulen rapat, agenda dan sebagainya. Dibandingkan dengan metode lain, maka metode ini tidak begitu sulit, dalam arti apabila ada kekeliruan sumber datanya masih tetap, belum berubah. Dengan metode dokumentasi yang diamati bukan benda tetapi benda mati.

Dalam menggunakan metode dokumentasi ini peneliti memegang check-list untuk mencari variabel 
yang sudah ditentukan. Apabila terdapat/muncul variabel yang dicari, maka peneliti tinggal membutuhkan check atau tally ditempat yang sesuai. Untuk mencatat hal-hal bersifat bebas atau belum ditentukan daftar variabel peneliti dapat menggunakan kalimat bebas.

Berdasarkan pendapat diatas penulis dapat menimpulkan bahwa metode dokumentasi adalah suatu metode yang digunakan untuk memperoleh dan mendapatkan data dengan cara mempelajari dan mencari data yang sudah didokumentasikan. Metode dokumentasi ini dimaksud untuk memperoleh data yang berasal dari surat-surat atau bukti-bukti serta catatan yang ada ditempat. Untuk memperoleh data tersebut dengan cara menghubungkan pihak yang akan dimintai keterangan mengenai dokumen yang diinginkan.

\section{Teknik Analisis Data}

Analisis data merupakan cara yang paling menentukan untuk menyusun data yang terkumpul, sehingga dapat menghasilkan suatu kesimpulan yang dapat dipertanggung jawabkan kebenarannya. Analisis data yang digunakan pada penelitian ini adalah data kualitatif. Data kualitatif digunakan untuk menentukan ketuntasan siswa keaktifan siswa dalam pembelajaran dikelas pada pembelajaran guru (peneliti) selama proses pembelajran berlangsung. Analisis data kualitatif adalah analisis data yang diperoleh dari hasil tes dan observasi.

Rafi'I (2002:23) menyatakan bahwa rumus yang digunakan dalam menganalisis ketuntasan belajar:

$\mathrm{P}=\quad \begin{gathered}\mathrm{n} \\ \mathrm{x} 100 \% \\ \mathrm{~N}\end{gathered}$

Keterangan:

$\mathrm{P}=$ presentase ketuntasan belajar siswa

$\mathrm{n}=$ jumlah siswa yang mencapai skor

tes $\geq 75$ dari skor maksimal 100

$\mathrm{N}=$ jumlah seluruh siswa

Kriteria ketuntasan belajar siswa dapat dinyatakan sebagai berikut:

a. Daya serap perorangan yaitu seorang siswa dikatakan tuntas belajar apabila telahmen capai skor $\geq 75$ dari skor tes maksimal 100.

b. Kriteria ketuntasan klasikal, suatu kelas dikatakan tuntas dalam belajar apabila dikelas 
tersebut telah telah terdapat minimal $85 \%$ yang mencapai skor tes $\geq 75$ dari skor tes maksimal 100 (SMK 2 Ibrahimy Sukorejo).

Presentase ketuntasan siswa :

$\mathrm{P}=\quad \mathrm{x} 100 \% \frac{\mathrm{N}}{\mathrm{M}}$

Keterangan :

$\mathrm{P}=$ Presentase ketuntasan siswa

$\mathrm{N}=$ Jumlah skor yang diperoleh

$\mathrm{M}=$ Jumlah skor maksimal

Dengan kriteria penilaian sebagai berikut:

\section{Kriteria ketuntasan}

\begin{tabular}{|l|l|}
\hline \multicolumn{1}{|c|}{ Presentase } & \multicolumn{1}{c|}{ Kategori } \\
\hline $\mathrm{P} \geq 90 \%$ & Sangat aktif \\
$80 \% \leq \mathrm{P}<90 \%$ & Aktif \\
$60 \% \leq \mathrm{P}<80 \%$ & Cukup aktif \\
$50 \% \leq \mathrm{P}<60 \%$ & Kurang aktif \\
$\mathrm{P}<50 \%$ & Tidak aktif \\
\hline
\end{tabular}

\section{HASIL PENELITIAN}

\section{Hasil Penelitian Prasiklus}

Pada prasiklus ini, peneliti menemukan masih banyak siswa yang hasil belajarnya dibawah ratarata (KKM 75) dan menganalisa serta mengevaluasi proses pemecahan masalah pada materi konsep teknologi jaringan komputer yang masih monoton tanpa ada kreasi-kreasi sehingga menyebabkan siswa bosan dalam kegiatan belajar mengajar di kelas. Dalam penelitian ini peneliti menerapkan pembelajaran yang mampu memecahkan masalah-masalah utama dalam belajar yaitu medel pembelajaran Aplikasi Cisco Packet Tracer, sehingga hasil ulangan harian siswa pada materi yang lalu tentang materi konsep teknologi jaringan komputer dengan rata-rata 60,00 dengan tingkat ketuntasan belajar $54 \%$ atau 13 siswa yang dapat dikatakan tidak tuntas.

\section{Hasil Penelitian Siklus}

\section{1. Perencanaan}

Kegiatan ini telah merealisasikan hal-hal yang telah direncanakan antara lain sebagai berikut:
a. Menyusun rencana pembelajaran
b. Membuat lembaran observasi mengajar
c. Menerima lembar observasi aktivitas belajar siswa


d. Menyusun soal dan kunci jawaban untuk pelaksanaan tindakan dan ulangan harian

e. Peneliti telah memberikan pengarahan dan pelatihan pembelajaran dengan menggunakan aplikasi Cisco Packet Tracer.

\section{Pelaksanaan Tindakan}

Berdasarkan perencanaan yang telah dipersiapkan sebelumnya, maka dilaksanakan tindakan penelitian dan observasi. Tindakan penelitian ini dilakukan pada kompetensi dasar menggunakan perbandingan untuk memecahkan masalah, yang terdiri dari tindakan pertemuan pertama dan kedua serta pelaksanaan ulangan harian. Sedangkan observasi dilakukan selama tindakan pembelajaran berlangsung dengan menerapkan pembelajaran yang menggunakan aplikasi Cisco Packet Tracer.

\section{Observasi}

Kegiatan observasi dimulai saat pelajaran di mulai sampai selesai untuk mengamati aktivitas belajar siswa dan aktivitas guru selama proses belajar mengajar berlangsung. Kegiatan observasi, peneliti dibantu oleh 1 observer yaitu guru produktif kelas $\mathrm{X}$ TKJ bernama Ahmad Muarif, S.Kom observer bertugas mengobservasi kegiatan siswa.

\section{Refleksi}

Refleksi dilakukan peneliti setelah proses pembelajaran berdasarkan analisis hasil observasi yang dilakukan oleh peneliti terhadap siswa selama proses pembelajaran berlangsung diketahui bahwa terdapat adanya peningkatan hasil belajar siswa dibandingkan dengan sebelum diadakannya tindakan, hal ini tampak pada hasil ulangan siswa setelah melakukan kegiatan pembelajaran.

Analisis $\quad$ yang dilakukan
terhadap ulangan
menunjukkan bahwa ketuntasan klasikal belum dicapai karena kurang dari $85 \%$ sehingga perlu diadakan siklus II. Hasil ulangan harian setelah pembelajaran pembelajaran aplikasi Cisco Packet Tracer menunjukkan bahwa siswa kurang dapat memahami materi. Hal ini terlihat dari ketuntasan klasikal yang dicapai 
sebesar 66\% dari 16 siswa yang tuntas dan $34 \%$ dari 8 siswa yang belum tuntas secara perorangan, hasil analisis dari siklus I.

Berdasarkan hasil observasi aktivitas siswa, hasil tes dan praktek dapat disimpulkan bahwa perlu adanya perbaikan pembelajaran pada siklus II terutama karena hasil siswa belum ternyata belum mencapai ketuntasan secara klasikal, sehingga dapat disimpulkan bahwa pada siklus I kurang berhasil untuk mencapai ketuntasan klasikal. Oleh karena itu, perlu adanya tindakan perbaikan dan penyempurnaan yang mengacu pada kekurangan dan hal-hal yang belum terlaksana pada siklus I, sehingga lebih dapat optimal dan sempurna lagi. Agar dapat mewujudkan hal tersebut, peneliti memutuskan untuk melaksanakan siklus berikutnya yaitu siklus II.

\section{Hasil Penelitian Siklus II}

\section{Perencanaan}

Berdasarkan hasil analisis hasil observasi siklus I. peneliti dapat mengidentifikasi kekurangan tindakan yang terjadi pada siklus I. adapun hal-hal yang dilakukan peneliti adalah memperbaiki kerurangan yang ada pada perencanaan siklus I. yaitu memberikan penghargaan atau pengakuan pada siswa yang telah melakukan aktivitas belajarnya dengan baik, pengendalian kelas pada saat proses pembelajaran berlangsung lebih diarahkan pada siswa yang pasif dan ramai sendiri, peneliti lebih memahami rencana pembelajaran yang telah disusun

lebih matang dan lebih memperhitungkan alokasi waktu yang tersedia. Sehingga kegiatan belajar mengajar yang direalisasikan sesuai dengan yang telah direncanakan. Adapun perencanaan yang lebih dibuat untuk melakukan perbaikan di siklus II adalah sebagai berikut.

a) Telah membuat rencana pembelajaran.

b) Telah membuat lembar observasi aktivitas belajar siswa.

c) Telah membuat lembar observasi guru mengajar.

d) Telah menyusun soal dan kunci jawaban untuk pelaksaan tindakan dan ulangan harian. 


\section{Pelaksanaan Tindakan}

Berdasarkan rencana perbaikan yang telah disiapkan dengan lebih matang, yang berpedoman atas kekurangan yang ada pada siklus I. Tahapan tindakan pada siklus II sama dengan tindakan siklus I. tindakan ini merupakan perbaikan pada siklus I dimana peneliti berupaya untuk meningkatkan hasil belajar siswa pada sub pokok bahasan yang sama dengan materi siklus I. tindakan siklus II terdiri dari 2 kali pertemuan dan 2 kali pertemuan observasi dilakukan

selama tindakan pembelajaran berlangsung.

\section{Observasi}

Kegiatan observasi dimulai saat pelajarandi mulai sampai selesai untuk mengamati aktivitas belajar siswa dan aktivitas guru selama proses belajar mengajar berlangsung. Kegiatan observasi, peneliti dibantu oleh 1 observer yaitu guru produktif kelas $\mathrm{X}$ TKJ bernama Ahmad Muarif, S.Kom observer bertugas mengobservasi kegiatan siswa.

\section{Refleksi}

Berdasarkan hasil tersebut diperoleh data dari 24 siswa yang mengikuti ulangan harian 3 siswa tidak tuntas belajar, karena siswa tersebut memperoleh nilai kurang dari 75 dari nilai maksimal 100 dan 21 siswa tuntas secara perorangan. Ketuntasan belajar secara secara klasikal pada siklus I hanya mencapai $66 \%$, pada siklus II ini sudah mencapai standar ketuntasan belajar klasikal sebesar $87 \%$.

Berdasarkan analisis observer hasil belajar siswa dari hasil nilai ulangan harian yang dilakukan terhadap siklus II, selama kegiatan berlangsung masih ada siswa yang kurang memperhatikan pelajaran, kurang bertangung jawab pada saat bermain peran dan masih ada siswa yang bergurau sendiri pada saat pelajaran berlangsung sehingga mereka tidak memahami betul materi yang di ajarkan serta tidak mau bertanya bila mengalami kesulitan. Tetapi suasana siklus tidak seramai pada siklus I karena guru sudah lancar menerapkan model pembelajaran aplikasi Cisco Packet Tracer. Hal ini terlihat saat guru bisa melakukan pengelolaan kelas dengan 
baik dan siswa tidak merasa bingung dengan model pembelajaran ini. Sehingga hasil belajar siswa mengalami peningkatan pada setiap siklusnya, sedangkan ketuntasan belajar $54 \%$ atau 11 siswa saja yang tutas pada saat peneliti belum menerapkan pembelajaran aplikasi Cisco Packet Tracer. Hal ini terlihat dari siswa sudah mulai mampu

beradaptasi dengan model pembelajaran yang baru diterapkan. Walaupun masih dalam masa transisi

dari model pembelajaran konvensional, sebagai siswa mampu mengikuti alur pembelajaran dengan baik dalam hal ini dibuktikan dengan ketuntasan belajar pada siklus I mencapai presentase $66 \%$ atau 16 siswa yang mampu beradaptasi dengan aplikasi Cisco Packet Tracer

dari prasiklus yang mampu meningkatkan hasil belajar siswa.

$$
\text { Peneliti mengadakan }
$$
perbaikan pada siklus II dengan mengubah strategi yaitu guru membimbing siswa melalui contoh-contoh soal pada siklus I agar siswa mampu mengatasi kesulitan belajar. Alhasil pada siklus II ada peningkatan sebesar $87 \%$ yang tuntas atau 21 siswa. Hasil siklus II peneliti tidak perlu mengadakan siklus selanjutnya karena siswa sudah mencapai ketuntasan belajar $87 \%$ dari nilai KKM yang ditentukan atau ditetapkan oleh SMK 2 Ibrahimy Sukorejo sebesar $85 \%$. Penelitian telah melebihi dari KKM yang telah diterapkan di sekolah tersebut.

\section{KESIMPULAN}

Berdasarkan hasil pembahasan maka peneliti mengambil kesimpulan bahwa : Pembelajaran dengan mengunakan aplikasi Cisco Packet Tracer mampu meningkatkan hasil belajar dari hasil ulangan pra siklus sebesar $54 \%$ meningkat pada siklus I dengan perolehan presentase ketuntasan siswa sebesar $66 \%$. Sedangkan siklus II mencapai ketuntasan belajar sebesar $87 \%$. Hal ini membuktikan bahwa pembelajaran aplikasi Cisco Packet Tracer mampu meningkatkan hasil belajar siswa. 


\section{DAFTAR PUSTAKA}

Arikunto, S.Dasar-Dasar Evaluasi

Pendidikan. Jakarta : Bumi

Aksara

Asyhar, R. 2012. Kreatif

Mengembangkan Media

Pembelajaran. Jakarta :

Referensi.

Dimyati Mudjiono, 2002.

Teknik-Teknik Penelitian

Kualitatif : Bandung

Hobri, 2007, Penelitian

Tindakan Kelas, Jember, Pena

Salsabila

Mariah, SY. 2005 : Skor

Hasil Belajar KajianTangan

Ditinjau Dari Metode Penilaian

Dan Gaya Kepemimpinan

Guru Dalam Jurnal Pendidikan

(No.1Vol.6). Jakarta :

Lembaga Pendidikan Universitas

Terbuka.

Madcoms, 2010. Dasar

Teknis Instalasi Jaringan

Komputer, Yogyakarta : Penerbit

Andi.

Mulyadi, 2014. Merancang

Bangun Dan Mengkonfigurasi
Jaringan WAN Dengan Packet

Tracer. Yogyakarta : Andi.

Nana Sudjana, R. Ibrahim,

1989. Penelitian Dan

Pendidikan, Penerbit Sinar

Baru, Bandung.

Prasetyo, 2007.

Sosiologi Pendidikan. Jakarta:

Universitas Terbuka.

Rusman, 2012. Manajemen

Kurikulum. Jakarta PT Raja

Grafindo Persada.

Sabar, 2007. Pengantar Metodologi Penelitian. FKIP

Universitas Muria Kudus.

Sudjana, 2003. Penilaian Hasil

Proses Belajar Mengajar.

Bandung : Remaja Rosdakarya.

Sugiono, 2011. Metodologi

Penelitian Kuantitatif,

Kualitatif, Dan $\quad R \& D$.

Bandung: Alfabeta.

Sunarto, 2009. Manajemen Mutu

Dalam Pendidikan Dan

Sosial. Edisi : Pertama.

Malang : Bayu

Media Publishing. 
Thabrani, Muhammad. 2011.

Belajar Pembelajaran.

Yogyakarta : Ar-Ruzz Media

Made wena, 2010.

Strategi Pembelajaran Inovatif

Kontemporer. Jakarta : Bumi

Aksara 